\title{
Characterization and evaluation of accessions of Bambara groundnut (Vigna subterranea (L.) Verdcourt) from Burkina Faso
}

\author{
Mahama Ouedraogo *, Jeremy T. Ouedraogo, Jean Baptiste Tignere, Didier Balma, Clémentine B. Dabire \& Gnissa Konate \\ Institut de l'Environnement de Recherches Agricoles (INERA), Département Production Végétales \\ 01 BP 2290 Ouagadougou 01, Tél : 00226503192 08, fax : 00226503402 71, \\ ${ }^{*}$ Corresponding Author (E-mail address. mahama.ouedraogo@messrs.gov.bf) \\ Reçu le 28-02-2006, accepté le 15-03-2007.
}

\begin{abstract}
Three hundred and ten (310) Bambara groundnut accessions mainly from the Northern semi arid zone of Burkina Faso were assessed for phenotypic variability of agronomic and morphological traits. Mixture of seed types in a given accession is common in Northern area of Burkina Faso. Two to twelve types of seeds compose the majority of accessions collected (82\%) and only $18 \%$ of accessions are homogeneous. Characters like canopy spread, number of pods per plant, number of seeds per pod, seed length, seed width and weight of 100 seeds are positively correlated to yield per plant. A negative correlation was revealed between days to $50 \%$ flowering and yield per plant indicating that plants which take more time on vegetative stage have less yield in semi-arid conditions of production. Accessions from Burkina assessed for agronomic and morphological characteristics in this study are less variable than 1384 accessions assessed by IITA in 1985 and 1986. This result can be explained by the restricted origin of accessions from Burkina Faso.
\end{abstract}

Keys words: Agronomic evaluation, Bambara groundnut, Mixture of seeds, Phenotypic variability, Vigna subterranea.

\section{Résumé}

Caractérisation et évaluation d'accessions de voandzou (Vigna subterranea (L.) Verdcourt) originaires du Burkina Faso

La variabilité phénotypique des traits agronomiques et morphologiques de 310 accessions de pois Bambara collectées principalement dans la zone semi aride nord du Burkina Faso a été évaluée. Le mélange de différents types de semences dans les accessions est une pratique répandue dans le Nord du Burkina Faso. Deux à douze types de semence composent la majorité des accessions (82\%) et seulement 18\% des accessions sont homogènes. Les caractères tels que la largeur du feuillage, le nombre de gousses par plante, le nombre de graines par gousse, la longueur et largeur des graines et le poids de 100 graines ont une corrélation positive avec le rendement en graine par plante. Une corrélation négative a été mise en évidence entre la date de $50 \%$ floraison et le rendement par plante montrant que les plantes qui prennent plus de temps pour leur phase végétative produisent moins dans les conditions de production semi arides. Les accessions du Burkina évaluées pour leurs caractéristiques agronomiques et morphologiques sont moins variables que les 1384 accessions évaluées par l'IITA en 1985 et 1986. Ce résultat peut s'expliquer l'origine restreinte des accessions originaires du Burkina.

Mots clés : Évaluation agronomique, Voandzou, Mélange de semences, Variabilité phénotypique, Vigna subterranea

\section{Introduction}

In spite of many efforts made to achieve food selfsufficiency in Burkina Faso by different actors, this status is not yet attained and protein malnutrition occurs in several communities. Most of the time, funds were provided to improve major cereals (sorghum, millet, maize and rice) and pulses like 
groundnut and cowpea. Agriculture in Burkina Faso is little performing due to constraints such as low soil fertility, drought and insufficient agricultural inputs. More attention to improve the production and the productivity of grain legumes can help to reach food self-sufficiency and its use can allow overcoming protein malnutrition. Bambara groundnut known under common names like "voandzou" in French, "souma" in mooré, is the second economically important grain legume after cowpea (Vigna unguiculata (L.) Walpers) in Burkina Faso.

Bambara groundnut is known as a well adapted crop to harsher conditions (Heller et al., 1997). Its seed is highly nutritious and chemical analyses showed that it contains $32.72 \%$ of total essential amino acids and $66.10 \%$ of total non-essential amino acids (Minka, Bruneteau, 2000; Amarteifio et al., 2006). Lysine is the major essential amino acid and represents $10.3 \%$ of the total essential amino acid. Bambara groundnut is also a good source of leucine and contains a reasonable amount of phenylalanine, histidine and valine. Really, Bambara groundnut seeds are a completely balanced food (Rowland, 1993) making it a good supplement to Burkinabé diet mainly based on cereal (sorghum, maize and millet).

In drier parts of sub-saharan Africa, Bambara groundnut is mainly grown by female (Ntundu et al., 2004) on a small scale, in pure culture without improved techniques. Research on Bambara groundnut has been very limited compared with investigation made on sorghum, millet, maize, peanut and cowpea (Drabo et al., 1997). Main results on Bambara groundnut improvement in Burkina Faso were obtained in plant pathology (Sérémé, 1989; Sérémé et al., 1991; Sérémé, 1992). There was no work on farming system, conservation techniques and plant breeding. Most of the previous germplasm collection of Bambara groundnut made in Burkina was lost. Improving cultural and storage techniques, pest and disease control and using potential genetic resource for plant breeding could increase production and productivity of Bambara groundnut (Evans, 1998). These observations justified the carrying out of an exploratory survey of farming system and a collecting of accessions from the provinces of Bam, Loroum, Soum and Yatenga. These activities are the first stage of a research program on the farming system and the reconstitution of Bambara groundnut genetic resources. The objective of this study is to: (I) show the phenotypic variability of seed coat and eye colour and pattern of Bambara groundnut accessions and (ii) characterize and evaluate Bambara groundnut accessions for agronomic traits. Characterization and evaluation of Bambara groundnut accessions from Burkina Faso is an action which is included in an effort made by the National Institute for Environmental and Agricultural Researches (INERA) to conserve and use the genetic resources of this "neglected and underutilized" crop.

\section{Material and methods}

The plant material consisted of 310 accessions. Three of them came from the collecting made in 1993 (Drabo et al., 1997). The remaining accessions (307) were collected in 2004 from producers in the Northern area of Burkina Faso. 254 accessions (82\%) are composed of two to twelve types of seeds according to the seed coat colour and pattern and only $18 \%$ of accessions are composed of one type of seed. The analysis of the variability of seed coat and eye colour and pattern was made according to the descriptors list of $V$. subterranea edited by the International Plant Genetic Resources Institute (IPGRI et al., 2000). During the collecting of accessions in 2004, an exploratory survey was made with the objective to obtain basic data on farming system of Bambara groundnut in Burkina Faso.

Field characterization and evaluation of the accessions was done during the rainy season of 2004 at the National Institute for Environmental and Agricultural Research (INERA) research station, located at Kamboinsé (12 km North of Ouagadougou). Seeds were sown in a ploughed sandy soil on rows spaced $40 \mathrm{~cm}$. Intra-rows spacing were $25 \mathrm{~cm}$. Each row was $5 \mathrm{~m}$ long and each accession occupied one row $(21$ seeds per accession were sown per row) without replication. Seventeen characters were used to assess the variability of Bambara groundnut accessions: emergence of seed at 14 days after sowing (EMF), days to first flowering ( $F F L)$, days to $50 \%$ flowering (HFL), plant height (PHT, cm), canopy spread (SPR, cm), number of pods per plant (POD), number of seeds per pod (SPP), number of pods with 1 seed (N1S), number of pods with 2 seeds (N2S), pod length (PDL, mm), pod width (PDW, mm), yield per plant (YLD, g), shell 
percentage (SHP, \%), yield per square meter (YMS, $\mathrm{g} / \mathrm{m} 2$ ), seed length (SDL, $\mathrm{mm}$ ), seed width (SDW, $\mathrm{mm}$ ) and weight of 100 seeds (WHS, g).

The analysis of agronomic and morphological data from evaluation and characterization was made by correlation. Correlation coefficients and associated probabilities between pairs of characters were calculated using the statistical software MINITAB. The correlation matrix helps to determine characters that vary in the same or opposite directions. Positive and negative correlations were found between traits (Goli et al., 1997). Correlations between pairs of characters are reliably significant when associated probabilities are less than $a=0.05$

\section{Results}

Most of the entries had a high rate of emergence (average rate of emergence is $83 \%$ ) and only $4 \%$ of the entries (13) didn't emerge at 14 days after sowing. Figure 1 illustrates the repartition of entries according to their rate of emergence.

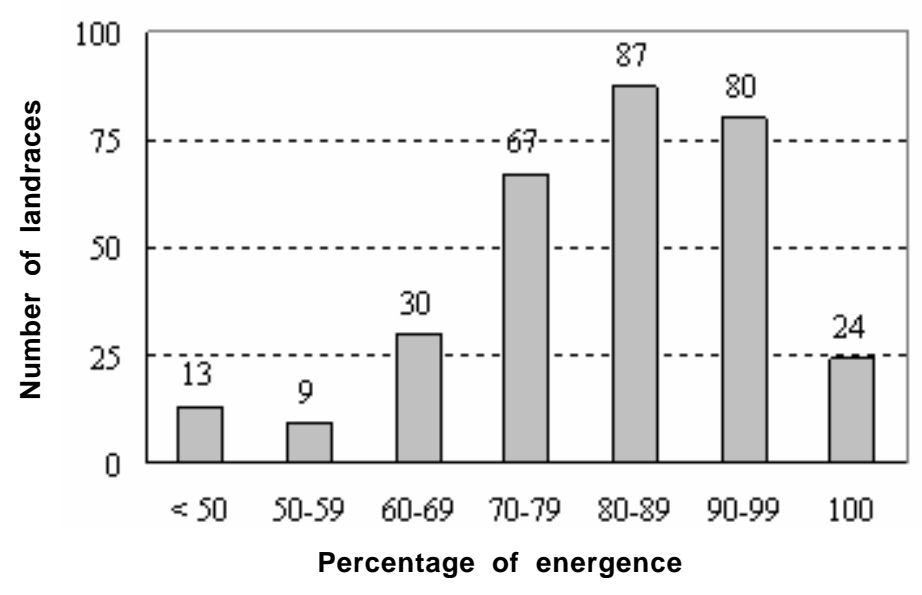

Figure 1: Frequency distribution of percentage of emergence

All the entries (310) are characterized by their relative homogeneity in flowering. The period to first flowering ranged from 30 to 33 days after sowing (DAS) (Figure 2). All the entries flowered in an interval of ten days (32 DAS to 42 DAS). Figure 3 illustrates the frequency distribution of period from sowing to $50 \%$ flowering (See Table I p 13).

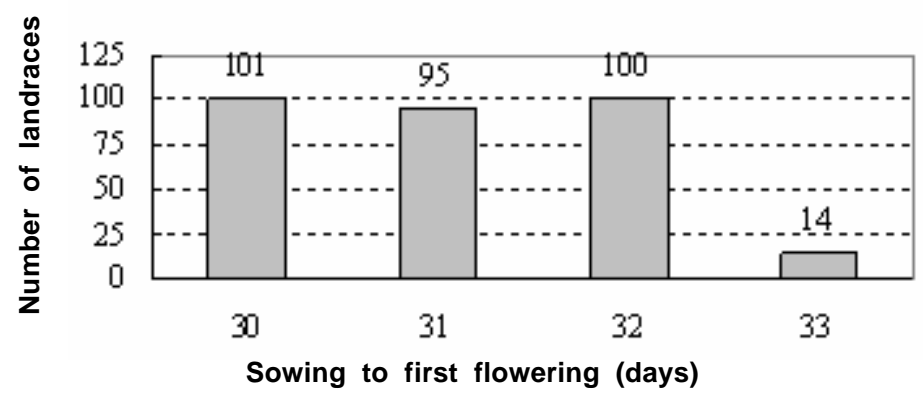

Figure 2: Frequency distribution of days from sowing to first flowering 


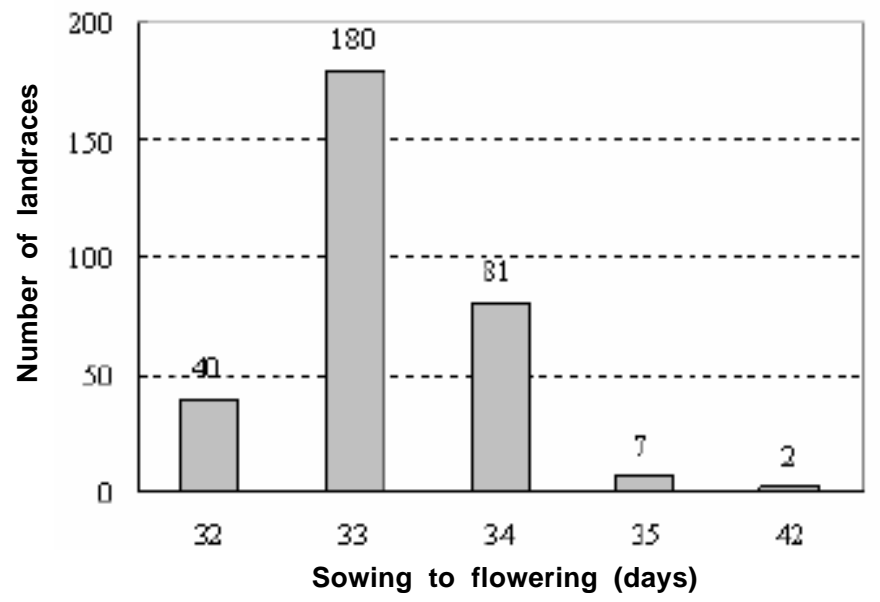

Figure 3: Frequency distribution of days from sowing to $50 \%$ flowering

The descriptive statistics of traits which were used to characterize and evaluate entries are listed in table 1.

Table 1. Descriptive statistics during the characterization and evaluation of Bambara groundnut accessions from Burkina Faso

\begin{tabular}{lcccccc}
\hline Character & N & Min. & Mean & Max. & SD & CV\% \\
\hline Emergence at fourteen days after sowing (EMF) & 310 & 19 & 80 & 100 & 14.16 & 17.60 \\
Days to first flowering (FFL) & 310 & 30 & 31 & 33 & 0.91 & 2.92 \\
Days to 50\% flowering (HFL) & 310 & 32 & 33 & 42 & 0.98 & 2.93 \\
Plant height (PHT), (cm) & 310 & 17 & 21 & 27 & 1.71 & 7.95 \\
Canopy spread (SPR), (cm) & 310 & 31 & 40 & 50 & 3.67 & 9.15 \\
Number of pods per plant (POD) & 310 & 4 & 24 & 50 & 6.59 & 27.68 \\
Number of seeds per pod (SPP) & 310 & 1 & 1.2 & 2 & 0.08 & 6.95 \\
Number of pods with 1 seed (N1S) & 310 & 2.6 & 19.8 & 41.2 & 6.15 & 31.07 \\
Number of pods with 2 seeds (N2S) & 310 & 0 & 4.0 & 13.9 & 1.80 & 45.10 \\
Pod length (PDL), (mm) & 310 & 10 & 19 & 24 & 1.38 & 7.08 \\
Pod width (PDW), (mm) & 310 & 8 & 10 & 15 & 0.77 & 7.43 \\
Yield per plant (YLD), (g) & 310 & 1.4 & 11 & 21 & 2.92 & 26.61 \\
Shell percentage (SHP), (\%) & 310 & 15 & 23 & 68 & 5.22 & 22.36 \\
Yield per square meter (YMS), (g/m2) & 310 & 11 & 83 & 144 & 26.01 & 31.18 \\
Seed length (SDL), (mm) & 310 & 9 & 11 & 14 & 0.69 & 6.04 \\
Seed width (SDW), (mm) & 310 & 7 & 9 & 11 & 0.52 & 5.72 \\
Weight of 100 seeds (WHS), (g) & 310 & 30 & 45 & 71 & 5.56 & 12.41 \\
\hline
\end{tabular}


The correlation matrix between pairs of characters is shown in table 2. Probability values $(p)$ for individual hypothesis test of null correlation are located under their respective correlation coefficients (upper numbers). Knowledge in association of characters through an analysis of correlation coefficients and their associated probabilities is important in breeding.

Table 2. Pearson correlation coefficients (upper numbers) followed by associated levels of probabilities (under numbers)

\begin{tabular}{|c|c|c|c|c|c|c|c|c|c|c|c|c|c|c|c|}
\hline FFL & $\begin{array}{c}\text { EMF } \\
-0.253 \\
0.000\end{array}$ & FFL & HFL & PHT & SPR & POD & SPP & N1S & $\mathrm{N} 2 \mathrm{~S}$ & PDL & PDW & YLD & SHP & SDL & SWL \\
\hline HFL & $\begin{array}{r}-0.181 \\
0.001\end{array}$ & $\begin{array}{l}0.229 \\
0.000\end{array}$ & & & & & & & & & & & & & \\
\hline PHT & $\begin{array}{r}-0.010 \\
0.862\end{array}$ & $\begin{array}{r}-0.160 \\
0.005\end{array}$ & $\begin{array}{l}0.001 \\
0.983\end{array}$ & & & & & & & & & & & & \\
\hline SPR & $\begin{array}{l}0.009 \\
0.870\end{array}$ & $\begin{array}{l}0.000 \\
0.998\end{array}$ & $\begin{array}{r}-0.161 \\
0.005\end{array}$ & $\begin{array}{l}0.229 \\
0.000\end{array}$ & & & & & & & & & & & \\
\hline POD & $\begin{array}{l}0.067 \\
0.237\end{array}$ & $\begin{array}{r}-0.081 \\
0.157\end{array}$ & $\begin{array}{r}-0.277 \\
0.000\end{array}$ & $\begin{array}{r}-0.003 \\
0.955\end{array}$ & $\begin{array}{l}0.161 \\
0.004\end{array}$ & & & & & & & & & & \\
\hline SPP & $\begin{array}{r}-0.119 \\
0.036\end{array}$ & $\begin{array}{l}0.041 \\
0.470\end{array}$ & $\begin{array}{l}0.071 \\
0.124\end{array}$ & $\begin{array}{l}0.132 \\
0.020\end{array}$ & $\begin{array}{l}0.012 \\
0.837\end{array}$ & $\begin{array}{r}-0.208 \\
0.000\end{array}$ & & & & & & & & & \\
\hline N1S & $\begin{array}{l}0.121 \\
0.033\end{array}$ & $\begin{array}{r}-0.092 \\
0.107\end{array}$ & $\begin{array}{r}-0.285 \\
0.000\end{array}$ & $\begin{array}{r}-0.042 \\
0.465\end{array}$ & $\begin{array}{l}0.135 \\
0.017\end{array}$ & $\begin{array}{l}0.961 \\
0.000\end{array}$ & $\begin{array}{r}-0.435 \\
0.000\end{array}$ & & & & & & & & \\
\hline $\mathrm{N} 2 \mathrm{~S}$ & $\begin{array}{r}-0.149 \\
0.009\end{array}$ & $\begin{array}{l}0.024 \\
0.672\end{array}$ & $\begin{array}{r}-0.047 \\
0.413\end{array}$ & $\begin{array}{l}0.128 \\
0.024\end{array}$ & $\begin{array}{l}0.137 \\
0.016\end{array}$ & $\begin{array}{l}0.376 \\
0.000\end{array}$ & $\begin{array}{l}0.714 \\
0.000\end{array}$ & $\begin{array}{l}0.107 \\
0.059\end{array}$ & & & & & & & \\
\hline PDL & $\begin{array}{r}-0.003 \\
0.959\end{array}$ & $\begin{array}{l}0.120 \\
0.034\end{array}$ & $\begin{array}{r}-0.017 \\
0.770\end{array}$ & $\begin{array}{l}0.120 \\
0.035\end{array}$ & $\begin{array}{l}0.281 \\
0.000\end{array}$ & $\begin{array}{l}0.030 \\
0.593\end{array}$ & $\begin{array}{r}-0.013 \\
0.816\end{array}$ & $\begin{array}{l}0.027 \\
0.635\end{array}$ & $\begin{array}{l}0.038 \\
0.500\end{array}$ & & & & & & \\
\hline PDW & $\begin{array}{r}-0.015 \\
0.792\end{array}$ & $\begin{array}{l}0.081 \\
0.154\end{array}$ & $\begin{array}{l}0.045 \\
0.434\end{array}$ & $\begin{array}{l}0.117 \\
0.039\end{array}$ & $\begin{array}{l}0.236 \\
0.000\end{array}$ & $\begin{array}{r}-0.079 \\
0.166\end{array}$ & $\begin{array}{r}-0.077 \\
0.175\end{array}$ & $\begin{array}{l}-0.056 \\
-0.056\end{array}$ & $\begin{array}{r}-0.095 \\
0.096\end{array}$ & $\begin{array}{l}0.539 \\
0.000\end{array}$ & & & & & \\
\hline YLD & $\begin{array}{l}0.026 \\
0.655\end{array}$ & $\begin{array}{l}0.060 \\
0.291\end{array}$ & $\begin{array}{r}-0.291 \\
0.000\end{array}$ & $\begin{array}{l}0.026 \\
0.648\end{array}$ & $\begin{array}{l}0.231 \\
0.000\end{array}$ & $\begin{array}{l}0.852 \\
0.000\end{array}$ & $\begin{array}{r}-0.035 \\
0.542\end{array}$ & $\begin{array}{l}0.778 \\
0.000\end{array}$ & $\begin{array}{l}0.463 \\
0.000\end{array}$ & $\begin{array}{l}0.194 \\
0.001\end{array}$ & $\begin{array}{l}0.092 \\
0.107\end{array}$ & & & & \\
\hline SHP & $\begin{array}{r}-0.047 \\
0.411\end{array}$ & $\begin{array}{l}0.127 \\
0.025\end{array}$ & $\begin{array}{l}0.300 \\
0.000\end{array}$ & $\begin{array}{r}-0.070 \\
0.221\end{array}$ & $\begin{array}{l}0.148 \\
0.009\end{array}$ & $\begin{array}{r}-0.172 \\
0.002\end{array}$ & $\begin{array}{r}-0.047 \\
0.408\end{array}$ & $\begin{array}{r}-0.157 \\
0.006\end{array}$ & $\begin{array}{r}-0.087 \\
0.124\end{array}$ & $\begin{array}{l}0.189 \\
0.001\end{array}$ & $\begin{array}{l}0.218 \\
0.000\end{array}$ & $\begin{array}{r}-0.199 \\
0.000\end{array}$ & & & \\
\hline SDL & $\begin{array}{l}0.056 \\
0.324\end{array}$ & $\begin{array}{l}0.158 \\
0.005\end{array}$ & $\begin{array}{l}0.028 \\
0.620\end{array}$ & $\begin{array}{l}0.070 \\
0.222\end{array}$ & $\begin{array}{l}0.215 \\
0.000\end{array}$ & $\begin{array}{l}0.073 \\
0.199\end{array}$ & $\begin{array}{r}-0.047 \\
0.414\end{array}$ & $\begin{array}{l}0.065 \\
0.215\end{array}$ & $\begin{array}{l}0.050 \\
0.384\end{array}$ & $\begin{array}{l}0.380 \\
0.000\end{array}$ & $\begin{array}{l}0.373 \\
0.000\end{array}$ & $\begin{array}{l}0.295 \\
0.000\end{array}$ & $\begin{array}{l}0.109 \\
0.056\end{array}$ & & \\
\hline SWL & $\begin{array}{l}0.007 \\
0.907\end{array}$ & $\begin{array}{l}0.092 \\
0.104\end{array}$ & $\begin{array}{l}0.019 \\
0.734\end{array}$ & $\begin{array}{r}-0.017 \\
0.760\end{array}$ & $\begin{array}{l}0.155 \\
0.006\end{array}$ & $\begin{array}{l}0.023 \\
0.684\end{array}$ & $\begin{array}{r}-0.102 \\
0.072\end{array}$ & $\begin{array}{l}0.031 \\
0.581\end{array}$ & $\begin{array}{r}-0.014 \\
0.800\end{array}$ & $\begin{array}{l}0.355 \\
0.000\end{array}$ & $\begin{array}{l}0.338 \\
0.000\end{array}$ & $\begin{array}{l}0.224 \\
0.000\end{array}$ & $\begin{array}{l}0.091 \\
0.110\end{array}$ & $\begin{array}{l}0.675 \\
0.000\end{array}$ & \\
\hline WHS & $\begin{array}{l}0.027 \\
0.633\end{array}$ & $\begin{array}{l}0.186 \\
0.001\end{array}$ & $\begin{array}{l}0.013 \\
0.814\end{array}$ & $\begin{array}{l}0.096 \\
0.092\end{array}$ & $\begin{array}{l}0.230 \\
0.000\end{array}$ & $\begin{array}{r}-0.054 \\
0.344\end{array}$ & $\begin{array}{r}-0.170 \\
0.003\end{array}$ & $\begin{array}{r}-0.010 \\
0.856\end{array}$ & $\begin{array}{r}-0.154 \\
0.007\end{array}$ & $\begin{array}{l}0.440 \\
0.000\end{array}$ & $\begin{array}{l}0.491 \\
0.000\end{array}$ & $\begin{array}{l}0.257 \\
0.000\end{array}$ & $\begin{array}{l}0.187 \\
0.001\end{array}$ & $\begin{array}{l}0.529 \\
0.000\end{array}$ & $\begin{array}{l}0.524 \\
0.000\end{array}$ \\
\hline
\end{tabular}

\section{Discussion}

The majority of entries (82\%) which was characterized and evaluated was composed of two to twelve types of seed and only $18 \%$ of entries were homogeneous. The practice of mixed seeds is a farmer strategy to secure crop production where rainfall is low, soil is poor, and crop productions are difficult to control (Brink et al., 2000). The cultivation of several genotypes in one field allows a minimum yield when biotic and abiotic conditions vary (Gallais, 1990). The Sahel area is characterized by low $(350-600 \mathrm{~mm})$ and erratic (high intra- and inter annual variability) rainfall, high evaporation rates and very high temperature fluctuations. 
The exploratory survey done during the collecting of accessions has shown that farmers name accessions mainly according to their colour and pattern of seed coat. Accessions, which have creamy to white seed coat colour, are most homogeneous due market demand. So, at the time of sowing and harvest, farmers avoid mixture on Bambara groundnut seeds which possess a white or creamy seed coat colour.

Farmers stated that their seed change from one year to another. Most of the time they take their seed for sowing from previous harvests. That can be explained of by the fact that (I) some genotypes are not fixed and there is a segregation in progeny (Karikari et al., 1997) (ii) seed sown are mixed and as farming conditions (rainfall, temperature, humidity, soil texture, structure and fertility, etc.) of each year can favour one or some genotypes to the detriment of others, only favoured genotypes will produce more progenies. So, the composition of seed will change from year to year according to previous environmental conditions.

To assess the real extent of genetic diversity of the Bambara groundnut accessions of Burkina Faso, agronomic, physiological, biochemical and molecular evaluation and characterization must be done as morphological genetic markers are limited (Kumar, 1999; Santoni et al., 2000). Nevertheless, agronomic evaluation and characterization are the first step in assessment of genetic diversity. Previous studies have shown that the choice of 15 to 20 agronomic characteristics is very useful to assess Bambara groundnut genetic diversity (Goli et al., 1997; Sesay et al., 2003).

Bambara groundnut accessions from Northern region of Burkina Faso are characterized by a high level of seedling emergence (mean of $83 \%$ ). These accessions have a short vegetative phase and a mean of flowering period of 33 days. Fresh seeds from most of accessions can be eaten at 75 to 80 after sowing.

For a breeding program, yield per plant is a major character. The nature of its association with others characters is a useful guide. Characters like canopy spread (SPR), number of pods per plant (POD), number of seeds per pod (SPP), seed length (SDL), seed width (SDW) and weight of 100 seeds (WHS) are positively correlated to yield per plant (YLD). A negative correlation was revealed between days to $50 \%$ flowering (HFL) and yield per plant (YLD) indicating that plants with longer vegetative stage yield less in our semi-arid area. Most of our accessions come from the Sahelian zone.
Our results are less variable than those obtained by IITA in the characterization and evaluation of 1384 accessions in 1985 and 1986 (Goli et al., 1997). These results can be explained by the fact that most of the accessions from Burkina Faso come from the semi arid zone (annual rainfall ranged between $350 \mathrm{~mm}$ and $600 \mathrm{~mm}$ ) while those of IITA come from various countries where Bambara groundnut is grown. All the accessions from Burkina Faso have a number of days to maturity less than 90 days while in IITA's collection, accessions have a mean days to maturity equal to 128 days with a minimum of 90 days and a maximum of 165 days (Goli et al., 1997). Considering the variation coefficient, Bambara groundnut accessions from Burkina Faso show high variability in number of pods per plant, shell percentage, weight of 100 seeds and seed weight per plant.

\section{Conclusion}

Accessions of Bambara groundnut mainly collected from Northern Burkina Faso showed that there is a phenotypic diversity in seed coat and eye colour and pattern. It is well known that phenotypic variability is a non exhaustive representation of genetic diversity. Agronomic and morphological evaluations have provided more accurate estimation of genetic diversity, the raw material of plant breeding. Our aim is to increase yield for semi arid environment. According to the correlation matrix, we can focus our selection on high number of pods per plant (POD), canopy spread (SPR), pod length $(\mathrm{PDL})$, seed length (SDL) and number of days to $50 \%$ flowering (HFL).

\section{Acknowledgments}

We acknowledge the National Project for the Development of Agricultural Services funded by the World Bank (PNDSA II) and Dr BALMA Didier through the project $C B D C$ for their financial support.

\section{Literature cited}

AMARTEIFIO J.O., TIBE O. et NJOGU R.M., (2006). The mineral composition of bambara groundnut (Vigna subterranea (L) Verdc) grown in Southern Africa. African Journal of Biotechnology 5: 2408-2411.

BRINK M., SIBUGA K.P., TARIMO A.J.P., et 
RAMOLEMANA G.M., (2000). Quantifying photothermal influences on reproductive development in bambara groundnut (Vigna subterranea): models and their validation. Field Crops Research 66: 1-14.

DRABO I., SÉRÉMÉ P., et DABIRÉ C., (1997). Bambara groundnut. In Heller J, Begemann F, \& Mushonga J, Eds. Conservation and improvement of Bambara groundnut (Vigna subterranea (L.) VerdC.) 19-26. Harare, Zimbabwe: IPGRI. pp 19-26

EVANS L.T., (1998). Feeding the ten billion. Plants and population growth. Cambridge, United Kingdom: Cambridge University Press. 247 pp.

GALLAIS A., (1990). Théorie de la sélection en amélioration des plantes. Paris, France: Editions MASSON. $588 \mathrm{p}$.

GOLI A.E., BEGEMANN F., et NG N.Q., (1997). Characterization and evaluation of IITA's bambara groundnut collection. In Heller J, Begemann F, \& Mushonga J, Eds. Conservation and improvement of Bambara groudnut (Vigna subterranea (L.) Verdc.), p. 101-118. Harare, Zimbabwe: International Plant Genetic Resources Institute. pp. 101-118

HELLER J., BEGEMANN F., et MUSHONGA J., (1997). Bambara groundnut Vigna subterranea (L.) Verdc. Conservation and improvement of Bambara groudnut (Vigna subterranea (L.) Verdc.). Harare, Zimbabwe: International Plant Genetic Resources Institute. pp 166.

IPGRI, IITA., et BAMNET., (2000). Descriptors for bambara groundnut (Vigna subterranea). International Plant Genetic Resources Institute, Rome Italy; International Institute of Tropical Agriculture, Ibadan, Nigeria; The International Bambara Groundnut Network, Germany. 57 pp.

KARIKARI S.K., WIGGLESWORTH D.J., KWEREPE B.C., BALOLE T.V., SEBOLAI B., et Munthali D.C., (1997). Country reports Botswana. In Heller J., Begemann F., et Mushonga J., Eds. Conservation and improvement of Bambara groudnut (Vigna subterranea (L.) Verdc.). Harare, Zimbabwe: International Plant Genetic Resources Institute. pp 17-24.

KUMAR L.S., (1999). DNA markers in plant improvement: An overview. Biotechnology Advances 17: 143-182.
MINKA S.R., et BRUNETEAU M., (2000). Partial chemical composition of bambara pea (Vigna subterranea (L.) Verde). Food Chemistry 68: 273-276.

NTUNDU W.H., BACH I.C., CHRISTIANSEN J.L., et ANDERSEN S.B., (2004). Analysis of genetic diversity in Bambara groundnut (Vigna subterranea (L.) Verdc) landraces using amplified fragment length polymorphism (AFLP) markers. African Journal of Biotechnology 3: 220-225.

ROWLAND R.J., (1993). Bambara groundnut. In Rowland JRJ, Eds. Dryland farming in Africa. London, UK: MacMillan Ltd. pp 278-282.

SANTONI S., FAIVRE-RAMPANT P., PRADO E., et PRAT D., (2000). Marqueurs moléculaires pour l'analyse des ressources génétiques et l'amélioration des plantes. Cahiers Agriculture 9: 311-327.

SÉRÉMÉ P., (1989). Seed borne pathogens of bambara groundnut (Vigna subterranea (L.) Verdcourt) in Burkina Faso and their significance. Copenhaguen, Denmark: Danish Government Institute of Seed Pathology for Developing Countries. 49 pp.

SÉRÉMÉ P., (1992). Les contraintes pathologiques à l'amélioration de la culture du voandzou au Burkina Faso: cas des maladies transmises par les semences. In Institut du Sahel, Eds. La lutte intégrée contre les ennemis des cultures vivrières dans le sahel. Bamako, Mali: Editions John Libbey Eurotext, Paris. pp 320-324.

SÉRÉMÉ P., KIWALLO L., et ZIDA E., (1991). Amélioration de la culture du voandzou (Vigna subterranea (L.) Verdcourt) au Burkina Faso par la lutte contre ses principaux pathogènes. In Wolf J.N., Eds. Influence du climat sur la production des cultures tropicales. Ouagadougou, Burkina Faso: International Foundation for Science (IFS) and Centre Technique de Coopération Agricole et Rurale (CTA). pp 357-364.

SESAY A., EDJE O.T., et MAGAGULA C.N., (2003). Agronomic performance and morphological traits of field-grown bambara groundnut (Vigna subterranea) landraces in Swaziland. In EU, INCODC, Eds. Proceedings of the International Bambara Groundnut Symposium. 8-12 September 2003. Botswana College of Agriculture, Botswana: European Union Framework programme 5 International Cooperation with Developing Countries. pp 47-63. 